\section{Negotiating a colonial Maya identity: metal ornaments from Tipu, Belize}

\author{
Bryan Cockrell, ${ }^{1}$ \\ Marcos Martinón-Torres, ${ }^{2}$ \\ Elizabeth Graham ${ }^{2}$
}

'Archaeological Research Facility, University of California, Berkeley, CA, USA; ' Institute of Archaeology, University College London, London, UK

\section{Abstract}

Archaeologists recovered Colonial-period metal ornaments from Tipu, Belize, the site of a Maya occupation from $300 \mathrm{BC}$ to $\mathrm{AD}$ 1707. This project asks to what extent the technological attributes of these ornaments reflect Mesoamerican or European influences. Investigators used microanalytical techniques, such as metallography, energy dispersive X-ray fluorescence (ED-XRF), electron probe microanalyser with energy dispersive spectroscopy (EPMA-EDS) and wavelength dispersive spectroscopy (EPMA-WDS) and surface etching, to study compositions and microstructures of the metals. Comparison of these data with technological and stylistic information of metals from other pre-Columbian and Contact-period sites reveals a confluence of indigenous and European metallurgy. Whereas the needle and bell forms and the suite of copper and bronze compositions align with indigenous metallurgical practices, the existence of lacetags and the use of brass reflect European technology. The presence of metal ornaments in association with Maya individuals in burials suggests that the Maya at Tipu were constructing and expressing new colonial identities through material markers.

\section{Introduction}

Archaeologists excavating the Spanish colonial-period occupation of Tipu recovered 99 metal objects from burials associated with the mission church or from secondary middens associated with contemporaneous residences. The most common categories of metals are bells, lacetags, needles, and rings. However, fishhooks, pendants, and scrap metal among other things also were recovered. This investigation aimed to characterise the metal technology at Tipu and the source(s) of its traditions. The investigators studied 61 of the metal objects with some form(s) of microanalysis [optical microscopy, energy dispersive X-ray fluorescence (ED-XRF), electron probe micro- analyser with energy dispersive spectroscopy (EPMA-EDS) and wavelength dispersive spectroscopy (EPMA-WDS) and etching with acidic reagents] in order to determine their compositions and microstructures. The Tipu metals then were compared technologically and stylistically with metals from other pre-Columbian and Contact-period sites in the Americas.

\section{Background}

Spanish colonial documents record the name Tipu for a visita mission. In 1978, archaeologists discovered the site on the west bank of the Macal River, opposite Macaw Bank (Graham et al., 1989) (Figure 1). Based on present evidence, Tipu was occupied from $c a$. $300 \mathrm{BC}$. Little is known about the Tipu Preclassic, but the community seems to have been occupied continuously into the Postclassic and Spanish colonial periods (Jones and Grant, 1989). Tipu's contact with Spanish authorities began $c a$. AD 1544, when the community was required to pay tribute. A church was constructed, and the community cooperated with Spanish tribute extractors and church authorities until AD 1638, when the Maya at Tipu joined a resistance movement led by the Itza Maya of Lake Petén (Jones and Grant 1989, 1998). Ties with Spanish authorities remained severely disrupted until AD 1695, when delegates visited Mérida to renew communications (Jones and Grant, 1989). In AD 1707, however, Spanish authorities relocated Tipu residents to Petén, in Guatemala (Jones and Grant, 1989, 1998).

\section{Context}

The cemetery, on the north, west, and south sides of the church and in its nave, contains over 600 Maya burials (Table 1). Of these, 270 are complete. Most of the bodies follow a Christian burial style: supine with heads facing west and arms folded or at the sides. The few exceptions show indigenous burial styles: flexed or seated (Cohen et al., 1997).

Several avenues were open for metals and other materials to circulate at Tipu. One option was local manufacture. At Postclassic Mayapán, archaeologists recovered crucibles containing sprues and fused bells, evidence of experimentation with lost-wax casting (Paris, 2008). That said, traces of primary processing of metals have been found only farther afield, such as at Postclassic-Colonial El Coyote (in Honduras) (Urban, 2007) and PostclassicColonial Itziparátzico (in Western Mexico) (Maldonado et al., 2005). This scarcity of evidence has led the investigators to look to other parts of Mesoamerica as potential sources of the Tipu metal.

Indigenous trade was another option for the appearance of materials at Tipu. At Early and Middle Postclassic Lamanai, metals from Western and Southern Mexico may have been exchanged for locally made ceramics (Simmons et al., 2009). Later, in 1502, off the
Correspondence: Bryan Cockrell, Archaeological Research Facility, University of California, 2251 College Building, 94720 Berkeley, CA, USA.

Tel./Fax: +1.510.642.2212.

E-mail: bryan.cockrell@berkeley.edu

Acknowledgments: the authors are grateful to Michael Wayman for permission to study the assemblage, Thilo Rehren for analytical and interpretive guidance, John Merkel for advice on etching, Simon Groom for laboratory support, and Kevin Reeves and Philip Connolly for support during use of EPMA.

Key words: Maya, Tipu, copper, brass, silver.

Citation: Cockrell B, Martinón-Torres M, Graham E, 2013. Negotiating a colonial Maya identity: metal ornaments from Tipu, Belize. In: RH Tykot (ed.), Proceedings of the $38^{\text {th }}$ International Symposium on Archaeometry - May $10^{\text {th }}-14^{\text {th }} 2010$, Tampa, Florida. Open Journal of Archaeometry 1:e24.

Presented at the $38^{\text {th }}$ International Symposium on Archaeometry - May $10^{\text {th }}-14^{\text {th }} 2010$, Tampa, Florida.

This work is licensed under a Creative Commons Attribution 3.0 License (by-nc 3.0).

(C) Copyright B. Cockrell et al., 2013

Licensee PAGEPress, Italy

Open Journal of Archaeometry 2013; 1:e24

doi:10.4081/arc.2013.e24

coast of Honduras, Columbus would encounter a canoe of Yucatán merchants carrying copper axes and bells along with cacao and pottery (Clendinnen, 1987). There is no reason to assume that this lively coastal trade would not continue into the colonial period.

Another option was trade through colonial networks. At El Chorro de Maíta, Cuba, an indigenous cemetery contained a wealth of brass, likely brought to Cuba by Spanish colonists (Martinón-Torres et al., 2007). The Spanish also may have introduced materials as gifts. Eighteen burials at the Tipu Colonial cemetery contain European glass beads, and two-thirds are children's burials (Smith et al., 1994). Spanish friars may have used the beads as rewards to children for learning the catechism. Indeed, friars Bartolomé de Fuensalida and Juan de Orbita departed Mérida for Tipu and Tayasal in 1618, carrying needles, glass beads, crosses, and rosaries (Jones and Grant, 1989).

Two factors complicate the investigation. First, there are no Spanish residences at Tipu. Thus, any contribution the Spanish made to the metal assemblage was the product of visits or trade. Second, there is no evidence of onsite metal fabrication. 


\section{Materials and Methods}

Discovered at Tipu in the mid-1980s, the metals first were analysed by Michael Wayman at the University of Alberta (Graham and Wayman, 1989). Eighty-one of the 99 objects were sent to the UCL Institute of Archaeology for further analysis. The metals were photographed and studied macroscopically for thickness, length, diameter, and other attributes. For microanalysis, some of the objects $(n=47)$ were studied by polishing a small surface area and keeping the object whole while others $(n=14)$ were sectioned and mounted in polished epoxy blocks. A Leica DMLM optical microscope (Leica, Wetzlar, Germany) was used for initial characterisation of the phases within the metals. For qualitative bulk compositional analysis, an InnovX Systems portable XRF Alpha 8000 LZX operating at $40 \mathrm{kV}$ was used on unprepared object surfaces. Compositional analysis of particular phases was accomplished through a JEOL JXA-8600 superprobe $(20 \mathrm{kV}$, working distance $=11 \mathrm{~mm}$, spot size $=5$ ), using 0xford instruments EDS and WDS detectors. Data was processed with the Inca microanalysis suite. For further imaging, a Philips XL30ESEM and a Hitachi S$3400 \mathrm{NSEM}(\mathrm{av}=20 \mathrm{kV})$ were employed. A naval brass and phosphoric bronze were analysed as reference materials to ensure accuracy and comparability between methods. After electron analysis, a $\mathrm{FeCl}_{2}$ etchant $(20 \% \mathrm{HCl})$ was applied for copper and its alloys, and an etchant of $3 \% \mathrm{H}_{2} \mathrm{O}_{2}$ (50\%), 25\% $\mathrm{NH}_{3} \cdot \mathrm{H}_{2} \mathrm{O}$ (25\%), and $\mathrm{H}_{2} \mathrm{O}$ (25\%) was applied for silver alloys prior to metallographic study.

We hoped to cover the entire typological spectrum of artifacts. Thus, approximately an equal number of bells, lacetags, needles, and rings were selected. Less numerous types (e.g. fishhooks) usually were studied with ED-XRF. Whether an object was studied whole or in section depended on concerns for its structural integrity as well as time constraints. For compositional analysis, the superprobe offered the advantage of identification of quantitative phase composition, while the non-invasive EDXRF could reveal generic patterns in alloy choice across many specimens. WDS was employed to resolve spectral ambiguities stemming from EDS.

\section{Results}

\section{Needles}

The Maya from Tipu may have used needles (Figure 2; Table 2) $(n=17,9)$ (note that the first number in parentheses is the number of objects of that type in the assemblage sent to the Institute of Archaeology. The second number is the number of objects of that type that were analysed in some fashion.) - long, solid rods with tapering ends - to fasten burial shrouds of the deceased. Sixteen of the 17 needles come from burials (the exception was found near a burial). Some of these needles were associated with specific locations on four

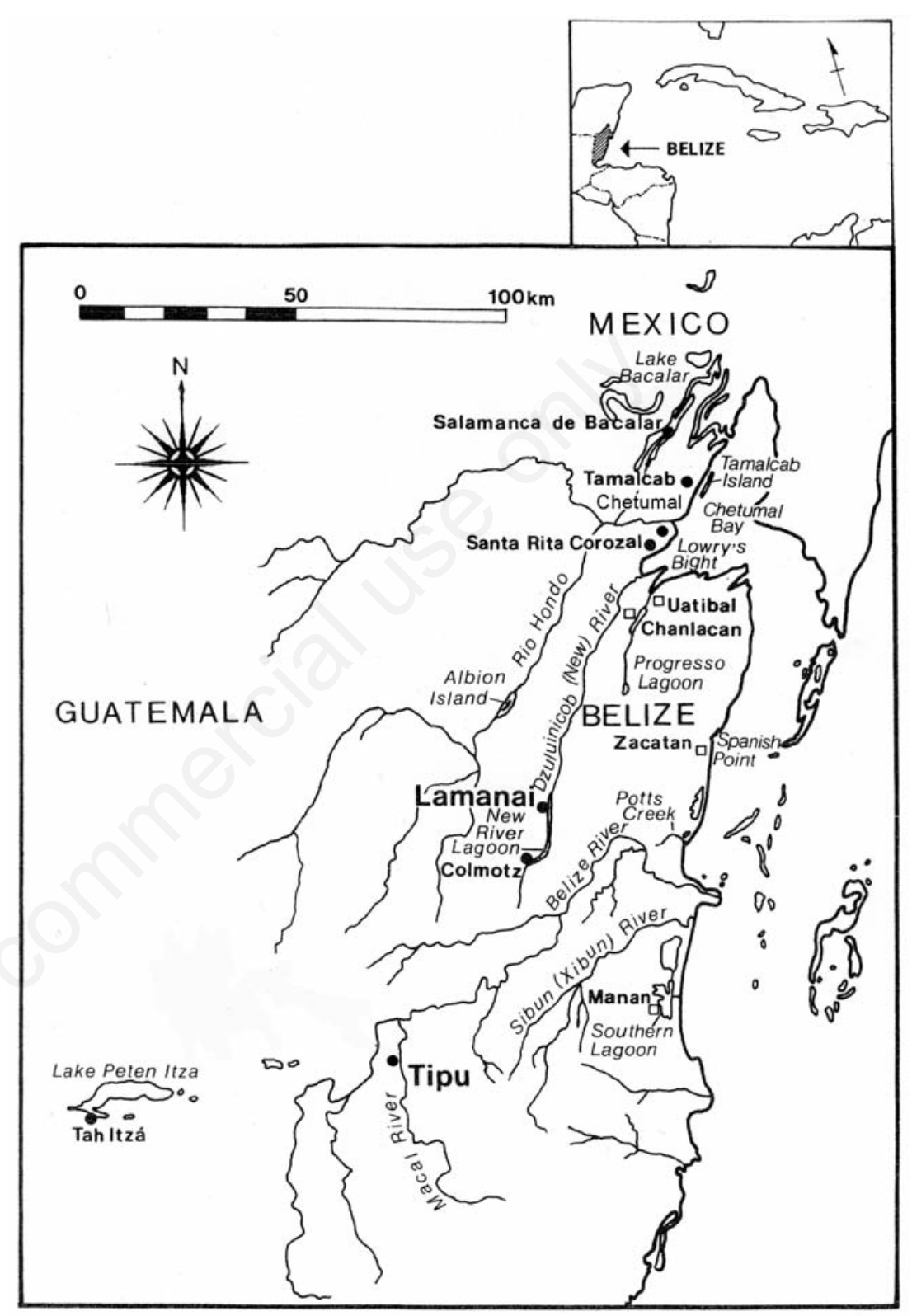

Figure 1. Map showing sites mentioned in the text including Tipu, Lamanai, and Lake Petén Itzá. Courtesy of Debora Trein.

Table 1. Contexts where objects were found.

\begin{tabular}{lccccccc} 
Object type & Burial & Surface findings & No context & Nidden & Near burial & Wall collapse debris & West nave \\
Needles & 16 & 0 & 0 & 0 & 1 & 0 & 0 \\
Lacetags & 8 & 0 & 0 & 0 & 0 & 0 & 0 \\
\hline Rings & 25 & 0 & 1 & 0 & 0 & 0 & 0 \\
Bells & 7 & 5 & 1 & 1 & 1 & 1 & 1 \\
\hline Total & 56 & 5 & 2 & 1 & & 0
\end{tabular}


different skeletons: the left tibia, the feet, the abdomen, and under the chin. Completely preserved needles $(n=13)$ have a mean length of $6.3 \mathrm{~cm}(\sigma=1.1)$. The mean thickness at the midpoint of the needles $(\mathrm{n}=17)$ is $0.18 \mathrm{~cm}$ $(\sigma=0.04)$.

\section{Elemental composition}

Five needles are brass and four are copper - frequently showing traces of lead and, occasionally, antimony. The brass needles are European in origin because brass production appears to have developed in the Americas only after European arrival (Martinón-Torres et al., 2007). The nickel content (0.1-0.4 wt \%) and the absence of arsenic in the brass needles is consistent with an Austro-Hungarian source (Mitchiner et al., 1987), whereas the source of copper remains uncertain.

\section{Craftsmanship}

Micrographs reveal that needles' shafts and eyes were fabricated from the same continuous piece of metal. In one case, textile fibers were observed attached to the needle's eye. The brass needles tend to be thinner (for brass, $0.16 \mathrm{~cm}$ on average, and for copper, 0.21 $\mathrm{cm}$ ). It appears that smiths hammered rectangular rods to form the needle's shafts and, in most cases, loop-shaped eyes, resembling the design of some Period II (AD 1200-1521) West Mexican needles (Hosler, 1994). European needles from this time, on the other hand, tend to be made from metal wire (Beaudry, 2006). This raises the possibility that indigenous metallurgists reworked European metal.

\section{Lacetags}

Some interred individuals were adorned with lacetags (Figure 3; Table 3) $(\mathrm{n}=11,11)$ short, hollow rods with tapering ends - to wrap loose ends of clothing. Micrographs show several specimens with cotton fibers attached.
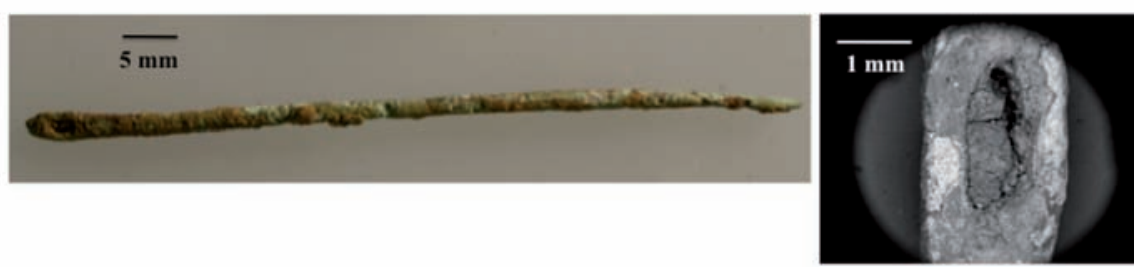

Figure 2. Needle 885.1 is pictured on the left. To the right, its loop eye is shown in a backscattered electron micrograph.

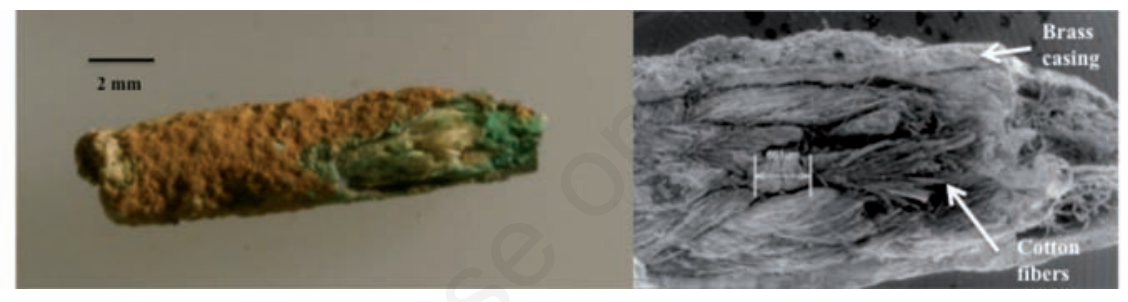

Figure 3. Lacetag 872.1 is pictured on the left. To the right, a backscattered electron micrograph reveals an area where the brass casing has eroded, exposing knots of cotton fibers.

Table 2. Composition of analysed needles.

\begin{tabular}{|c|c|c|c|c|c|c|c|c|c|c|c|}
\hline Needle & 0 & Si & Ti & Mn & $\mathrm{Fe}$ & $\mathrm{Ni}$ & $\mathrm{Cu}$ & $\mathrm{Zn}$ & As & $\mathrm{Sb}$ & $\mathrm{Pb}$ \\
\hline 512.1 & & & + & - & + & + & + & - & & - & + \\
\hline 516.1 & 8.5 & 0.5 & & & 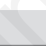 & & 89.9 & & $\operatorname{tr}$ & $<0.5$ & 0.6 \\
\hline 518.1 & & & + & - & + & - & + & - & & - & + \\
\hline 859.2 & & & + & - & + & + & + & - & & - & + \\
\hline 513.1 & & & - & - & + & - & + & + & & - & + \\
\hline 851.3 & & & + & - & + & + & + & + & & - & + \\
\hline 862.1 & & & + & + & + & - & + & + & & - & + \\
\hline 885.1 & & & + & - & + & + & + & + & & - & + \\
\hline 908.1 & 4.8 & & $x$ & & & & 73.5 & 21.7 & & & \\
\hline
\end{tabular}

+ , presence in energy dispersive X-ray fluorescence analysis; -, absence in energy dispersive X-ray fluorescence analysis; tr, trace concentration; <, element detected in one or two of the three analyses. The first four needles listed are predominantly copper, and the next five are brass. All results represent the means of three analyses.

Table 3. Composition of analysed lacetags.

\begin{tabular}{|c|c|c|c|c|c|c|c|c|c|c|c|c|c|}
\hline Lacetag & 0 & Al & $\mathrm{P}$ & S & Cl & Ti & $\mathrm{Fe}$ & Ni & $\mathrm{Cu}$ & $\operatorname{Zn}$ & As & Sn & $\mathrm{Pb}$ \\
\hline 497.2 & & & & & & + & + & + & + & + & + & - & + \\
\hline 852.2 & & & & & & + & + & + & + & + & - & - & + \\
\hline 853.1 (2 analyses) & 2.5 & 0.5 & & & & & & & 63.6 & 33.4 & & & $\operatorname{tr}$ \\
\hline 871.1 (1 analyses) & 9.5 & & & & 0.3 & & & & 90.2 & & & & \\
\hline 872.1 & & & & & & + & + & + & + & + & - & - & + \\
\hline 890.1 & 1.4 & & $\operatorname{tr}$ & $\operatorname{tr}$ & & & $\operatorname{tr}$ & 0.3 & 75.2 & 23.1 & & & $\operatorname{tr}$ \\
\hline 890.2 & 1.3 & & & & & & & & 75.1 & 23.6 & & & \\
\hline 895.2 & & & & & & - & + & + & + & + & - & + & + \\
\hline 900.2 & $\operatorname{tr}$ & & & & $\operatorname{tr}$ & & & & 72.6 & 27.4 & & & $\operatorname{tr}$ \\
\hline $901.1-4$ & & & & & & + & + & + & + & + & - & - & + \\
\hline $902.1-2$ & & & & & & - & + & + & + & + & - & - & + \\
\hline
\end{tabular}

+ , presence in energy dispersive X-ray fluorescence analysis; -, absence in energy dispersive X-ray fluorescence analysis; tr, trace concentration. All results represent the means of three analyses. 
One lacetag was associated with the chest of one skeleton, and another with the pelvis of a different skeleton. Two lacetags come from adult male burials. The average length of the apparently complete lacetags $(\mathrm{n}=3)$ is $1.9 \mathrm{~cm}$ $(\sigma=0.6)$. They are thicker than the needles at their midpoints: on average, this thickness is $0.29 \mathrm{~cm}(\mathrm{n}=9, \sigma=0.04)$. Lacetags are found in a variety of American contexts from this approximate time period, including the sites of El Chorro de Maíta and La Habana in Cuba and Jamestown and New England in the United States colonies. Illustrations of men and women in $15^{\text {th }}$ century continental Europe show the application of lacetags to clothing (Egan and Pritchard, 2002).

\section{Elemental composition}

Ten lacetags are brass and a highly corroded one appears to be copper ( $90 \mathrm{wt} \% \mathrm{Cu}$, although the zinc might have been lost through dezincification). Localised copper sulfide and lead inclusions (5-10 $\mu \mathrm{m}$ on their long axes) were identified in cross section. There is no evidence of the cementation technique for brassmaking in the Americas before the arrival of Europeans.

\section{Craftsmanship}

Smiths rolled rectangular sheets leaving a seam running the length of the lacetag. The rolling technique and associated seam are also evident on lacetags from Colonial Cuba and New England as well as Medieval London. A gradient of increasing grain coarseness from edge to center suggests that smiths applied light deformation to hone the lacetag's shape. In one etched lacetag, the observation of distorted annealing twins implies the application of coldworking as the final treatment. In another, straight annealing twins suggests either coldworking followed by annealing or hotworking. In any case, the shape and design of these objects support a European origin.

\section{Rings}

The deceased Maya from Tipu were adorned with ring-shaped objects (Figure 4; Table 4) ( $n=24$ individual rings, 18 of which are in pairs, 15 analysed) in their hair or on their ears or fingers, as suggested by the rings' archaeological contexts. A given burial has no more than one pair of rings. Among the 22 rings found in burials, four were associated with juvenile burials, six with women, and one with a man. Indeed, an important pattern at Tipu is that, of all of the female burials containing metal objects, all have at least one ring. Among all burials, four rings were found in cranial regions, and two were attached to one woman's forefinger. With only one exception (a square-sectioned brass ring), these rings are thin circular rods with rectangular or circular cross sections, and they are often fastened with a separate, tightly wrapped metallic coil. The thickness of these coils is half of the thickness of the central rings. The average diameter of the central rings $(\mathrm{n}=22)$ is $1.7 \mathrm{~cm}(\mathrm{~s}=0.2)$.
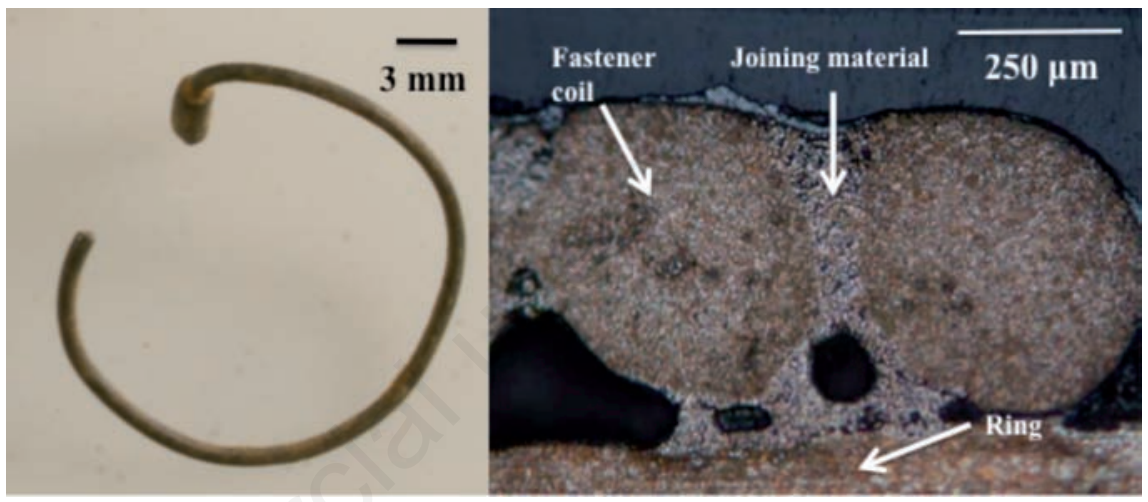

Figure 4. Ring 854.2 is pictured on the left. To the right, the ring is shown after etching, illustrating that the ring and fastener coil have a different microstructure from that of the joining material.

Table 4. Composition of analysed rings.

\begin{tabular}{|c|c|c|c|c|c|c|c|c|c|c|c|c|c|c|}
\hline Ring & 0 & Mg & Al & Si & S & $\mathrm{Cl}$ & $\mathrm{Fe}$ & $\mathrm{Cu}$ & $\mathrm{Zn}$ & $\mathrm{Br}$ & $\mathrm{Ag}$ & $\mathrm{Au}$ & $\mathrm{Pb}$ & $\mathrm{Bi}$ \\
\hline 104.1 & & & & $\operatorname{tr}$ & & $\operatorname{tr}$ & 0.3 & 69.9 & 28.5 & & & & $<1.3$ & \\
\hline 511.1 & $<3.5$ & 0.4 & & 0.4 & 0.6 & $<0.4$ & & 1.1 & & & 93.6 & & & \\
\hline 517.1 & & 0.3 & & & & 4.7 & & 2.7 & & 0.8 & 90.0 & & 1.5 & \\
\hline 521.1 & & & & & 0.4 & 7.5 & & 2.1 & & & 89.1 & 0.9 & & \\
\hline 854.2 (ring) & & 0.3 & & & & & & 7.1 & & & 92.6 & & & \\
\hline 854.2 (fastener) & & 0.4 & & & & & & 6.0 & & & 93.0 & & $<0.6$ & \\
\hline 854.2 (joining material) & 3.9 & 0.3 & & & & 0.5 & & 6.6 & & & 87.8 & & $<0.9$ & \\
\hline 855.1 & & & & & & & + & + & & & + & & + & - \\
\hline 856.1 & & & & & & & + & + & & & & & + & + \\
\hline 864.1 & & & & & & & + & + & & & & & + & - \\
\hline 864.2 & & & & & & & + & + & & & & & + & - \\
\hline 866.1 & & & & & & & + & + & & & & & + & - \\
\hline 866.2 & & & & & & & + & + & & & & & + & + \\
\hline 874.1 & 2.6 & & 0.3 & 0.5 & 0.3 & 4.0 & & 2.7 & & & 89.6 & & & \\
\hline 874.2 & & $<0.4$ & & 0.3 & 0.2 & 4.0 & & 3.8 & & 0.5 & 90.8 & & & \\
\hline 875.1 & & & & & & & + & + & & & + & & + & + \\
\hline 875.2 (ring) & & 0.4 & & & & 0.3 & & 5.4 & & & 92.5 & 0.7 & $<0.7$ & \\
\hline 875.2 (joining material) & & 0.3 & & & & $<0.3$ & & 5.5 & & & 93.2 & 0.7 & & \\
\hline
\end{tabular}

tr, trace concentration; +, presence in energy dispersive X-ray fluorescence analysis; -, absence in energy dispersive X-ray fluorescence analysis; <, element detected in one or two of the three analyses. The first ring is brass, while the remaining rings are Ag-Cu alloys. All results represent the means of three analyses. 
Their average thickness $(\mathrm{n}=23)$ is $0.11 \mathrm{~cm}$ $(\sigma=0.03)$.

\section{Elemental composition}

Fourteen rings are silver-copper alloys, and only one is brass ( $28 \mathrm{wt} \% \mathrm{Zn}$, with traces of lead). Trace amounts of lead (0.1-0.5 wt $\%)$ in the silver rings suggest that cupellation would have been employed for silver extraction. The $\mathrm{Ag}-\mathrm{Cu}$ rings were generally free of inclusions, but high $\mathrm{Pb}$ ( $>50 \mathrm{wt} \%$ ) inclusions were detected in the brass ring. While silver alloys are far from normal in Pre-Columbian Mesoamerica, they are not completely absent. Thus, lacking clear stylistic comparanda and lead isotopic data, the origin of the silver remains uncertain.

\section{Craftsmanship}

Longitudinal striations on the surfaces of the rings imply that smiths formed them by drawing metal blanks through a die. The variation in shape and separation of lines in the patterns and the variation in rod cross-section suggests that a number of different dies were employed. In cross-section, the rings and their fastener coils consist of coarse, equiaxed grains of $\alpha$ surrounded by a $\beta$ film, while they appear to have been joined together by brazing or soldering with a metal of very similar composition, now appearing as dendritic $\alpha$. This structure reflects the manufacturing process, which would involve the drawing and annealing of the different coils before joining them with the rings. The unadorned form of the rings resembles the style of bronze rings found attached to skeletons from West Mexico and Ecuador (Hosler 1994, 1988). However, we know of no European or Mexican parallels for the fastening method.

\section{Bells}

Bells (Figure 5; Tables 5 and 6$)(n=15,13)$ - spherical, hollow objects often with external

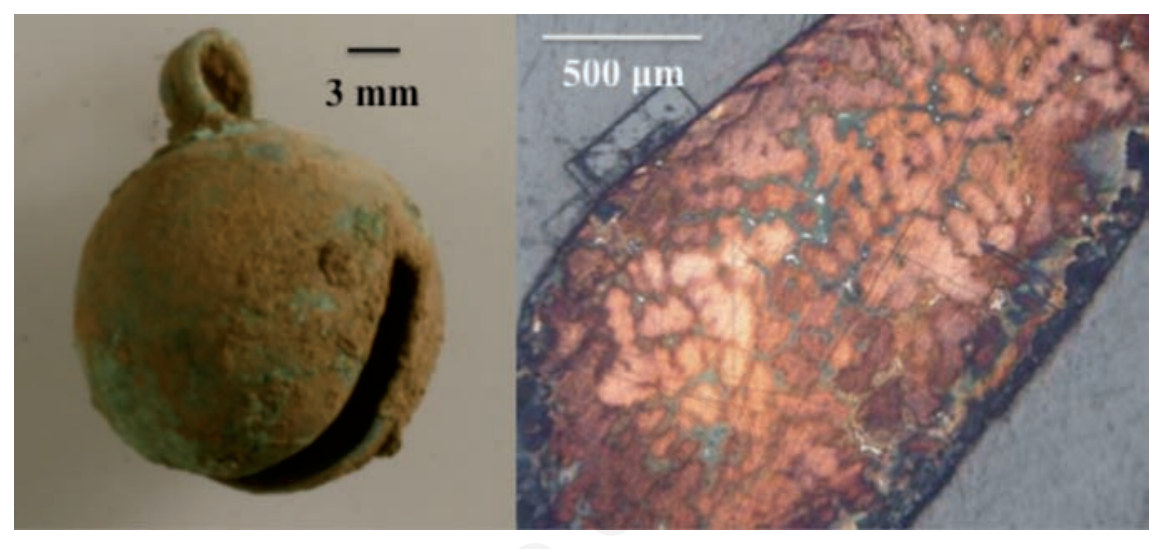

Figure 5. Bell 902 is pictured on the left. To the right, the bell is shown after etching, revealing its as-cast microstructure.

Table 5. Composition of analysed bells.

\begin{tabular}{|c|c|c|c|c|c|c|c|c|c|c|c|c|c|c|c|c|}
\hline Bell & 0 & Si & S & Cl & Ti & $\mathrm{Mn}$ & $\mathrm{Fe}$ & Ni & $\mathrm{Cu}$ & As & Se & Ag & Sn & Sb & $\mathrm{Pb}$ & Bi \\
\hline 050.2 & 2.9 & & & 1.9 & & & & & 91.1 & 1.9 & & & & & 2.2 & \\
\hline $129.1^{*}$ & & $<0.03$ & 0.09 & $<0.13$ & & & 0.46 & $<0.07$ & 97.68 & 0.05 & & 0.18 & 0.07 & 0.11 & 1.13 & \\
\hline 145.1 & & 0.4 & $\operatorname{tr}$ & & & & & & 99.1 & $\operatorname{tr}$ & & 0.5 & & & $\operatorname{tr}$ & $\operatorname{tr}$ \\
\hline 161.1 & & & & & + & + & + & + & + & + & & - & + & - & + & - \\
\hline 162.2 & & & & & + & - & + & + & + & + & & + & + & + & + & + \\
\hline 191.1 & & & & $<0.3$ & 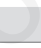 & & 0.5 & & 98.6 & tr & & $<0.6$ & & $\mathrm{tr}$ & & $\operatorname{tr}$ \\
\hline $198.1^{*}$ & & 0.42 & 0.16 & 2.84 & & & 0.06 & 0.12 & 93.53 & 0.03 & & 0.53 & 0.41 & 0.28 & 1.18 & 0.44 \\
\hline 515.1 & & & & & + & - & + & - & + & + & & - & - & - & + & - \\
\hline 850.22 & & & & & + & - & + & - & + & - & & - & + & - & + & - \\
\hline 850.23 & & tr & $\operatorname{tr}$ & $\operatorname{tr}$ & & & & & 98.0 & 2.0 & tr & $\mathrm{tr}$ & & & tr & \\
\hline 850.24 & & & & & + & - & + & - & + & - & & - & + & + & + & - \\
\hline 887.1 & & & & & - & + & + & - & + & - & & - & + & - & + & - \\
\hline 902 & & 0.3 & $\operatorname{tr}$ & & & & $\operatorname{tr}$ & & 97.1 & $\operatorname{tr}$ & $\operatorname{tr}$ & & 2.6 & & & \\
\hline
\end{tabular}

tr, trace concentration; +, presence in energy dispersive X-ray fluorescence analysis; - , absence in energy dispersive X-ray fluorescence analysis; <, element detected in one or two of the three analyses. ${ }^{*}$ Data from WDS, employed for resolution between As and Pb peaks. All results represent the means of three analyses.

Table 6. Results of analyses of two reference standards.

\begin{tabular}{|c|c|c|c|c|c|c|c|c|c|c|c|c|c|c|c|c|c|}
\hline $\begin{array}{l}\text { Reference } \\
\text { material }\end{array}$ & Method & 0 & Al Si & $P$ & $\mathrm{Cl}$ & $\mathrm{Ca}$ & $\mathrm{Ni}$ & Ti & $\mathrm{Mm}$ & $\mathrm{Fe}$ & $\mathrm{Cu}$ & $\ln$ & As & $\mathrm{Ag}$ & Sn & Sb & Au \\
\hline CURM 42.23-2 & Reference values & & 0.0050 .015 & 0.128 & 0.045 & & 0.168 & & 0.019 & 0.354 & 74.36 & 22.13 & 0.168 & & 1.63 & 0.356 & 0.5750 .034 \\
\hline Admiralty and & ED-XRF & & & & & & 0.2 & & & 0.3 & 73.6 & 22.8 & & & 1.7 & 0.3 & 1.0 \\
\hline \multirow[t]{2}{*}{ Navy Brass } & EPMA-EDS & & & & & & & & & 0.3 & 75.6 & 22.5 & & & 1.6 & & \\
\hline & EPMA-WDS & & & & $<0.02$ & $<0.01$ & & & & 0.27 & 74.67 & 22.11 & $<0.07$ & $<0.03$ & 1.72 & 0.19 & $<0.06<0.05<0.29$ \\
\hline CCRMP 293 & Reference values & & & & & & & & & 0.026 & 94.59 & 0.037 & & & 4.96 & & 0.01 \\
\hline \multirow[t]{3}{*}{ Phosphor bronze } & ED-XRF & & & & & & & & & & 94.30 & 0.2 & & & 5.5 & & \\
\hline & EPMA-EDS & 1.6 & & & & & & & & & 93.0 & & & & 5.3 & & \\
\hline & EPMA-WDS $(n=4)$ & & & & $0.05 \quad 0.02$ & 0.04 & & 0.04 & & & 94.30 & & & 0.03 & 5.47 & & 0.03 \\
\hline
\end{tabular}

ED-XRF, energy dispersive X-ray fluorescence; EPMA-EDS, electron probe micro-analyser energy-dispersive spectroscopy; EPMA-WDS, electron probe micro-analyser wavelength dispersive spectroscopy. 
loops for attachment, open mouths, and intact clappers - were found primarily in two burials at Tipu. Within one burial, four bells were found: one under the left radius, one under the right radius, one under an armpit, and one under a lumbar vertebrae. Three bells were found in a pair of juvenile burials, and one was found on the chest of another skeleton, likely to be male. Five other bells were found less than $20 \mathrm{~cm}$ below the surface. Two bells were associated with glass beads, and two were carved to show a mammalian face [like the head effigy type defined by Lothrop (1952:91)] The bells' total length $(\mathrm{n}=11)$ is, on average, $2.1 \mathrm{~cm}(\sigma=0.5)$. Their average body length (their total length without considering the length of their loop) $(n=14)$ is $1.6 \mathrm{~cm}(\mathrm{~s}=0.5)$.

\section{Elemental composition}

Smiths made the bells from a diverse range of compositions: four are copper, three are $\mathrm{Cu}$ $\mathrm{Pb}$, two are $\mathrm{Cu}-\mathrm{Sn}$, two are $\mathrm{Cu}-\mathrm{Pb}-\mathrm{As}$, and one is $\mathrm{Cu}$-As. Surface XRF analysis of a fully corroded bell yielded $\mathrm{Pb}-\mathrm{Sn}$, but this may not be representative. In addition, traces of $\mathrm{Ag}, \mathrm{Bi}$, and $\mathrm{S}$ were found in a number of bells. The generally low levels of elements other than copper (typically $\leq 2 \mathrm{wt} \%$ ) and their overall variability suggest that these artifacts may have been produced with unrefined metal from polymetallic ores or, more likely, by melting scrap that was recycled indiscriminately.

\section{Craftsmanship}

The predominance of dendritic microstructures and the identification of sprues on the surfaces imply that the bells were lost-waxcast. The use of the lost-wax casting process is evident in West Mexico and at Lamanai and Mayapán and is recorded in the Colonial Florentine Codex. A lack of porosity reveals the smiths had fine-tuned their casting setup.

\section{Discussion}

No evidence of primary or secondary metal processing has been recovered from Tipu, which suggests that the metal ornaments were not manufactured locally. However, there are several other avenues to explain their occurrence: indigenous trade, the colonial trade network, or products of evangelisation. A combination of these sources may have led to the appearance of each object type.

Given their resemblance to West Mexican loop-eye needles, the Tipu needles may have been designed in Mesoamerica. Their raw material may have come from a combination of indigenous sources (for copper needles) and European sources (for brass needles). Mesoamerican metallurgists may have melted European brass objects and cut and shaped needles from this metal.

The lacetag form, on the other hand, appears to have European origins. The fact that these lacetags are brass implies that these objects may have been the result of trade with colonists, with no indigenous recycling and manufacturing.

Rings of similar design have been recovered across the Pre-Columbian Americas, but rings made of silver alloys are atypical. PreColumbian silver mines have been detected at Hidalgo, at Pachuca, and near the Rio Grande (Lothrop, 1952), and ethnohistoric documents record the significant silver wealth in the Tarascan state. Without isotopic comparison among the Tipu rings, the Pre-Columbian silver deposits, and European silver ores, it is impossible to pinpoint the silver source(s).

Bells from Tipu are readily comparable to bells from other Maya sites such as Chichén Itzá, Lamanai, and Mayapán. The Tipu bells' varied bronze compositions and suite of trace elements indicate that metal from a variety of indigenous sources may have been remelted, mixed, and then cast. This operation may have been performed at several locations, which then sent the bells to Tipu. The addition of glass beads to two bells may have been an indigenous idea, or colonists may have come across the bells and inserted glass beads they were bringing from Europe.

\section{Conclusions}

The metal objects analysed served either as adornments (bells, lacetags, rings) or were part of ritual practices associated with burial (needles). Both Mesoamerican and European traditions played a role in their production. The confluence of traditions reflected in the metals at Tipu is manifested in other ways. For example, Christian-style internment occurs alongside Precolumbian practices, such as the caching of objects on the transverse axis of a Colonial-period building (Graham, 1991). The lack of permanent Spanish residents at Tipu and the difficulty the Spanish faced in controlling the Maya hinterland introduced conditions in which the Maya at Tipu could exercise relative freedom in forms of expression and in the construction of a local identity. Metal objects, however they reached Tipu, occurred in a variety of forms, were appropriated by a variety of individuals, and were valued enough to serve as accompaniments in death. Importantly, it is likely that the re-contextualisation of European metals and artifact types was accompanied by a transformation in their value and meaning.

Within the Tipu metal inventory, there is diversity in composition and design. One ring is made of brass (instead of $\mathrm{Ag}-\mathrm{Cu}$ ) and fas- tened with a rivet (instead of a wire loop), bells display a range of bronze alloys, and there are small quantities of objects unique from the four central forms, such as fishhooks and pendants. Whatever the stimulus for object choice, the channels bringing metals to Tipu clearly facilitated diversity in the assemblage.

In the future, further analysis of metal ores in Mesoamerica and Lower Central America must be performed (and analyses of European ores considered) in order to begin tying Tipu's metal objects to particular sources of raw material.

\section{References}

Beaudry MC, 2006. Findings: the material culture of needlework and sewing. Yale University Press, New Haven.

Clendinnen I, 1987. Ambivalent conquests. Cambridge University Press, Cambridge.

Cohen MN, O'Connor K, Danforth ME, Jacobi KP, Armstrong C, 1997. Archaeology and osteology of the Tipu site. In: L. Stephen Whittington and D. M. Reed (eds.) Bones of the Maya: studies of ancient skeletons. Smithsonian Institution Press, Washington, DC, pp 78-86.

Egan G, Pritchard F, 2002. Dress accessories 1150-1450. The Boydell Press, Woodbridge, UK.

Graham E, 1991. Archaeological insights into colonial period Maya life at Tipu, Belize. In: D.H. Thomas (ed.) Columbian consequences, Vol. 3: the Spanish borderlands in Pan-American perspective. Smithsonian Institution Press, Washington, DC, pp 319-35.

Graham E, Pendergast DM, Grant D, 1989. On the fringes of conquest: Maya-Spanish contact in colonial Belize. Science 246:1254-9.

Graham E, Wayman M, 1989. Maya material culture at conquest: copper and other artifacts from colonial Tipu, Belize. In: 88th Annual Meeting of the American Anthropological Association, 15-19 November, Washington, DC.

Hosler D, 1988. Ancient West Mexican metallurgy: South and Central American origins and West Mexican transformations. Am Anthropol 90:832-55.

Hosler D, 1994. The sounds and colors of power. The MIT Press, Cambridge, MA.

Jones GD, 1989. Maya resistance to Spanish rule: time and history on a colonial frontier. University of New Mexico Press, Albuquerque, NM.

Jones GD, 1998. The conquest of the Last Maya kingdom. Stanford University Press, Stanford, CA.

Lothrop SK, 1952. Metals from the Cenote of 
Sacrifice, Chichen Itzá, Yucatán. Peabody Museum, Cambridge, MA.

Maldonado BE, Rehren TH, Howell PR, 2005. Archaeological copper smelting at Itziparátzico, Michoacán, Mexico. In: B.P. Vandiver, L.J. Mass, A. Murray (eds.) Material issues in art and archaeology VII. Materials Research Society ed., Warrendale, PA, pp 231-40.

Martinón-Torres M, Rojas RV, Cooper J, Rehren $\mathrm{TH}, 2007$. Metals, microanalysis and meaning. J Archaeol Sci 34:194-204.
Mitchiner MB, Mortimer C, Pollard AM, 1987.
Nuremberg and its Jetons, c. 1475 to 1888 : chemical compositions of the Alloys. The Numismatic Chronicle 147: 114-55.

Paris E, 2008. Metallurgy, Mayapan, and the Postclassic Mesoamerican world system. Ancient Mesoam 19:43-66.

Simmons SE, Pendergast DM, Graham E, 2009. The context and significance of copper artifacts in Early Postclassic and Early Historic Lamanai, Belize. J Field Archaeol 34:57-75.
Smith MT, Graham E, Pendergast DM, 1994. European beads from Spanish colonial Lamanai and Tipu, Belize. Beads: Journal of the Society of Bead Researchers 6:2147.

Urban P, 2007. Rural production in Northwest Honduras: the 2004 season of the Lower Cacaulapa Valley Archaeological Project. FAMSI. Available from: http://www.famsi. org/reports/03030/ 